\title{
NOWE MATERIAŁY I PROCESY W KONWERSJI ORAZ PRZECHOWYWANIU ENERGII - WYBRANE ZAGADNIENIA
}

\begin{abstract}
Na podstawie studiów literaturowych wybrano i przytoczono przykłady obecnie stosowanych technologii i materiałów do konwersji oraz przechowywania energii. Mając na uwadze $\mathrm{z}$ jednej strony rosnące zapotrzebowanie na energię, z drugiej zaś bogactwa naturalne oraz warunki klimatyczne, wybrano kilka zagadnień, dla których w zarysie przedstawiono obecny stan badań oraz podano literaturę. Studia literaturowe przeprowadzono, opierając się na bazach danych SciFinder i Current Contents, w perspektywie ostatnich czterech lat. Tylko w wyjątkowych przypadkach sięgano do starszej literatury.
\end{abstract}

Słowa kluczowe: węgiel brunatny, naturalny gaz ziemny, wodór jako paliwo, organiczny cykl Rankine'a, konwersja energii, magazynowanie energii

\section{Wstęp}

Autorzy pracy objęli przeglądem następujące paliwa węglowe: węgiel brunatny, gaz ziemny oraz alternatywne paliwa do silników spalinowych. Na kształt tego rozdziału miał wpływ artykuł pod redakcją prof. J.M. Tobina (Northwestem University, Evanston, USA) [1]. Dokumentował on dyskusję, która się odbyła w Santa Fe (stan Nowy Meksyk, USA) w 1999 r., w gronie naukowców z doświadczeniem akademickim i przemysłowym nad badaniami przemian węgla w obecności katalizatorów. W spotkaniu brali również udział reprezentanci różnych dziedzin nauk podstawowych oraz politycy. Zestaw zagadnień, które poddano dyskusji, proponując pewne rozwiązania na najwyższym obecnie poziomie naukowym, obejmowat:

- wytwarzanie i zastosowanie wodoru,

- aktywację i zastosowanie niskocząsteczkowych węglowodorów,

- aktywację i zastosowanie ditlenku węgla,

\footnotetext{
1 Autor do korespondencji/corresponding author: Jerzy Zoń, Politechnika Wrocławska, Wybrzeże Wyspiańskiego 27, 50-370 Wrocław, tel.: (71) 3203910, e-mail: jerzy.zon@pwr.edu.pl.

2 Zbigniew Gnutek, Politechnika Wrocławska, e-mail: zbigniew.gnutek@pwr.edu.pl.
} 
- nowe kierunki badań nad katalizą,

- katalizatory dla silników napędzających pojazdy o zwiększonej sprawności [1].

W ciągu prawie 15 lat od chwili ukazania się tego artykułu nastąpiła zmiana ważności zagadnień oraz radykalnie zmienił się stan wiedzy w poszczególnych obszarach.

Przegląd przemian, procesów i reakcji chemicznych zachodzących podczas termochemicznych transformacji stałych paliw węglowych przedstawiono w bieżącej literaturze $[63,64]$. Wydaje się, że przyczyną transformacji zachodzących w różnych strefach jednego reaktora lub w różnych reaktorach są reakcje następcze zachodzące $\mathrm{w}$ polu temperatur i stężeń reagentów w reakcjach częściowo heterofazowych (ciało stałe-gaz), a częściowo homofazowych (gaz-gaz). Ten złożony układ może być dodatkowo komplikowany przez zastosowanie katalizatora przyspieszającego jedną reakcję chemiczną lub większą ich liczbę. Dlatego precyzyjne badanie i opis tego typu układu jest bardzo trudny i prawie zawsze wymaga uproszczenia. W celu lepszego poznania transformacji zachodzących w układzie i tym samym możliwości wywierania wpływu na transformację dąży się do oddzielnego badania jej poszczególnych etapów $[63,64]$.

\section{Węgiel brunatny}

Zagadnieniu reagowania lotnych składników z pozostałością po odgazowaniu paliwa i wpływu tego procesu na pirolizę lub gazyfikację niskogatunkowych paliw węglowych poświęcono artykuł przeglądowy [30]. W innym artykule zostały omówione sposoby suszenia niskogatunkowych paliw węglowych [43]. W tym miejscu warto wspomnieć o publikacji, w której zaproponowano klasyfikację niskogatunkowych paliw, ułatwiającą podjęcie decyzji o sposobie wykorzystania paliwa [5]. Przedmiotem przeglądu literaturowego była woda zawarta w niskogatunkowych węglach, z uwzględnieniem jej rodzaju, oddziaływania ze strukturą paliwa i wpływu na proces transformacji w wyższych temperaturach [61]. Kolejny artykuł dotyczył właściwości węgla brunatnego z różnych złóż w Stanie Wiktoria w Australii, istotnych z punktu widzenia sekwestracji ditlenku węgla [45]. Badano emisję metali podczas spalania karbonizatów w atmosferze tlenu lub powietrza, otrzymanych w wyniku pirolizy dwóch gatunków węgla brunatnego [33]. Nie stwierdzono istotnej różnicy w emisji pierwiastków między różnymi sposobami spalania. Wyniki badania mechanizmu samozapłonu niskogatunkowych węgli przedstawiono w innej publikacji [18].

Kolejna spośród wybranych prac dotyczyła wpływu rozmiaru ziarna węgla brunatnego na właściwości mechaniczne karbonizatu [65]. Do zagadnień badanych eksperymentalnie $\mathrm{w}$ instalacjach pilotażowych należy spalanie węgla brunatnego $\mathrm{w}$ atmosferze mieszaniny tlen-ditlenek węgla $[10,11]$. W monografii [16] szeroko omówiono podstawy oraz rodzaje technologii spalania w pętli 
węgla. Systemy spalania w pętli chemicznej przebiegają w dwóch reaktorach: powietrznym oraz paliwowym. Paliwo jest wprowadzane do reaktora paliwowego, w którym reaguje z nośnikiem tlenu w formie utlenionej (np. tlenek żela$\mathrm{za}(\mathrm{III}) \mathrm{Fe}_{2} \mathrm{O}_{3}$ ). Strumień gazu opuszczającego reaktor paliwowy składa się $\mathrm{z}$ ditlenku węgla i pary wodnej. Po kondensacji pary wodnej uzyskuje się skoncentrowany strumień ditlenku węgla. Zredukowany nośnik tlenu (np. tlenek żelaza(II,III) $\mathrm{Fe}_{3} \mathrm{O}_{4}$ ) jest kierowany do reaktora powietrznego, gdzie następuje ponowne utlenienie nośnika powietrzem (np. do tlenku żelaza(III) $\mathrm{Fe}_{2} \mathrm{O}_{3}$ ), a następnie zawrócenie do reaktora paliwowego. Strumień gazu opuszczającego reaktor powietrzny składa się głównie $\mathrm{z}$ azotu oraz nieprzereagowanego tlenu. Całkowita ilość ciepła wydzielonego $\mathrm{w}$ trakcie procesu jest identyczna $\mathrm{z}$ ilością ciepła wydzielonego $\mathrm{w}$ trakcie normalnego spalania paliwa $\mathrm{w}$ atmosferze powietrza lub tlenu. Gazyfikacja węgla brunatnego lub alternatywnego paliwa stałego w reaktorze paliwowym, w temperaturze ok. $1000 \mathrm{~K}$, może zachodzić w obecności nośnika tlenu, takiego jak hematyt [37], który jest minerałem lub handlowego tlenku żelaza (III) [51]. W badaniach przeprowadzonych z nośnikiem tlenu zawierającym żelazo, otrzymanym jako odpad w produkcji boksytu, ilość uwalnianej rtęci, głównie w postaci rtęci metalicznej, zależy od temperatury reaktora i zawartości rtęci w paliwie [38].

\section{Naturalny gaz ziemny}

Przedmiotem artykułu przeglądowego [23] są: transport, dystrybucja i wykorzystanie ciekłego gazu ziemnego. Omówiono procesy od skraplania poprzez przemianę do fazy gazowej, aż do spalania u odbiorcy oraz antycypowane kierunki rozwoju i zagrożenia mogące się pojawić podczas eksploatacji według tej technologii. W artykułach wstępnych $[6,14]$ w dwóch czasopismach, w których opublikowano materiały z 10. Sympozjum Konwersji Gazu Naturalnego (NGCS-10, Doha, Katar, 2013), przedstawiono w sposób syntetyczny postępy w tej dziedzinie. W 41 artykułach opublikowanych w czasopismach Catalysis Today (vol. 228) i Industrial \& Engineering Chemistry Research (vol. 53, z. 5) zaprezentowano postępy w konwersji gazu ziemnego. Jako przykład wybrano jedną publikację z tych materiałów, opisującą wyniki badań nad spalaniem metanu w pętli z użyciem nośnika tlenu [4]. W innym artykule przedstawiono obliczone parametry modelowanej turbiny gazowej, przy zastosowaniu modelu reaktora Aspen RGibbs. Czynnikiem termodynamicznym był metan, spalany w dużym nadmiarze powietrza [34]. Parametrem limitującym pracę układu była maksymalna temperatura zespołu komory spalania.

Ostatnio zostały opublikowane wyniki eksperymentalne współspalania słomy ryżowej w gazie ziemnym, w złożu fluidalnym, w atmosferze powietrza [42]. W badaniach wykorzystano palnik nowszej konstrukcji. Osiągnięto wyższą temperaturę w komorze spalania, która wpłynęła pozytywnie na spadek emisji tlenku węgla i zmniejszyła straty węgla. W innej publikacji badano wpływ 
udziału tlenu w powietrzu oraz dodatku ditlenku węgla na spalanie gazu naturalnego oraz skład spalin [28].

\section{Alternatywne paliwa do silników spalinowych}

Ostatnio ukazał się artykuł przeglądowy podsumowujący dotychczasowe osiągnięcia w dziedzinie wytwarzania i wykorzystania paliw gazowych ze źródeł odnawialnych [59]. Można stwierdzić, że w przyszłości potrzebne będą długotrwające badania pracy silników zasilanych tego typu paliwami oraz zmiany w ustawieniu zapłonu przy zmianie składu paliwa. Przed projektantami i konstruktorami prototypów nowej generacji silników Diesla zasilanych mieszaniną powietrza i wodoru lub powietrza i gazu ziemnego, a następnie ich sprężania aż do wystąpienia samozapłonu, stoi wiele wyzwań [21]. Spośród nich można wymienić: kontrolę samozapłonu paliwa, odprowadzenie ciepła przy większych mocach czy spełnienie limitów emisji szkodliwych składników spalin. W projektowaniu bardzo pomocne są metody numeryczne, które mogą zredukować liczbę koniecznych doświadczeń w celu konstrukcji prototypu. Ostatnio ukazała się praca przeglądowa na temat ewolucji biopaliw ciekłych i gazowych do silników Diesla [12]. Biopaliwa czwartej generacji, wykorzystujące analizę i wcześniejsze osiągnięcia technologiczne, pozwolą obniżyć koszt jednostkowy paliwa (głównie podyktowany wysokimi kosztami inwestycyjnymi) oraz umożliwią większą wydajność przekształcania surowców odnawialnych w biopaliwo.

Następny artykuł przeglądowy przedstawia i objaśnia podstawy fizyczne braku odporności paliwa biodiesla na utlenianie oraz proponuje sposób zapobiegania utlenianiu paliwa przez dodatek antyutleniaczy [58]. Przegląd technologii wytwarzania bioetanolu z różnych surowców oraz jego rola w bilansie paliw to temat innego artykułu [56]. Przedmiotem badań było również porównanie sprawności termicznej i objętościowej oraz map emisji składników spalin w silniku Diesla zasilanym komercyjnym paliwem, mieszaniną dwuskładnikową paliw (paliwo diesel-naturalny gaz) oraz mieszaniną trójskładnikową paliw (paliwo diesel-naturalny gaz-paliwo biodiesel) [56].

\section{Wodór jako paliwo}

Wodór jest szczególnym paliwem ze względu na produkt spalania. Z tego powodu istnieje duże zainteresowanie sposobami wytwarzania wodoru jako nośnika energii $(33,3 \mathrm{kWh} / \mathrm{kg})$. Ostatnio ukazała się monografia obejmująca wytwarzanie, przechowywanie i zastosowanie wodoru [62]. W skali przemysłowej największe ilości wodoru otrzymuje się w wyniku konwersji gazu ziemnego $[4,6]$ w obecności pary wodnej i katalizatora. Obserwuje się postępy w technologii konwersji różnych surowców [13, 55] i metanolu [26] do wodoru, ale największe zainteresowanie w ostatnich latach wzbudza otrzymywanie wodoru na drodze fotokatalitycznego rozkładu wody z zastosowaniem odnawialnej energii 
słonecznej $[9,22,25]$. W ocenie autorów najlepszym źródłem informacji na temat postępów w przechowywaniu wodoru jest monografia [62]. Z przeglądu dotyczącego zastosowania węgli aktywnych do przechowywania energii można się dowiedzieć o problemach związanych z dokładnymi i powtarzalnymi pomiarami adsorpcji wodoru na nośniku stałym [52]. Pewną nadzieję w dalszym rozwoju materiałów do adsorpcji wodoru stwarzają porowate materiały krystaliczne, ściślej - sieci hybrydowe zbudowane z jonów metali i związków organicznych, oznaczane akronimem MOF [60].

\section{Organiczny cykl Rankine’a}

Niedawno ukazał się przegląd termodynamicznych cykli i roboczych czynników, które są proponowane do zagospodarowania ciepła odpadowego [8]. Różne zastosowania organicznego cyklu Rankine'a (ORC) zagospodarowujące niskotemperaturowe ciepło przedstawiono $\mathrm{w}$ artykule [53]. W kolejnych publikacjach zostały omówione czynniki robocze i wybór ekspandera [2] oraz techniczno-ekonomiczna analiza [48] dla ORC. Zwrócono uwagę na potencjał płynący z zagospodarowania odpadowej energii cieplnej silników spalinowych [50], która stanowi energię równoważną około $50 \%$ energii zawartej w użytym paliwie. Wstępne wyniki eksperymentalne $\mathrm{z}$ instalacji laboratoryjnej oraz opis termodynamiczny mikro- i makroukładów ORC z zastosowaniem łopatkowego ekspandera opisano $\mathrm{w}$ pracy [19].

\section{Wybrane przykłady konwersji energii}

W bieżącej literaturze w dyscyplinach „termodynamika” i „energia” ukazują się publikacje opisujące nowe procesy - najczęściej znane, ale w nowy sposób zintegrowane - oraz nowe materiały. Doniesienia te pozwalają na proponowanie nowych rozwiązań dotychczasowych problemów. Dalej przytoczono kilka przykładów z literatury. Idea bezpośredniej zamiany fotonu światła słonecznego w prąd elektryczny lub w nośnik energii jest prawdopodobnie największym wyzwaniem naukowym i technologicznym naszych czasów [41]. Szczególne urządzenie polifunkcyjne, w skrócie opisywane jako „sztuczny liść”, jest przykładem realizacji tego typu zamierzeń [27]. Chociaż prace badawcze nad obecnymi na rynku wodorowymi ogniwami paliwowymi nie są zakończone, to podjęcie badań nad rozwojem idei ogniwa paliwowego zasilanego węglem brunatnym jest interesujące [49]. Realizowane są również badania materiałowe nad nowymi krystalicznymi ciałami stałymi typu MOF, posiadającymi zdolność przewodzenia protonów $\mathrm{w}$ podwyższonej temperaturze [3]. Projektowanie i konstrukcja magnesów nadprzewodzących będących źródłem bardzo silnych pól magnetycznych jest również aktualnym wyzwaniem [36, 47]. Zaproponowano nowy sposób zagospodarowywania niskotemperaturowego ciepła, wykorzystując do tego celu ogniwo termogalwaniczne [29]. Zainteresowanie mogą wzbudzić wyniki 
otrzymane dla prototypu ulepszonego płaskiego kolektora po zastosowaniu nowych materiałów [17].

\section{Przechowywanie energii}

$\mathrm{Na}$ temat magazynowania różnych form energii ukazał się artykuł przeglądowy [35]. Ukazały się także artykuły przeglądowe w obszarach przechowywania poszczególnych form energii: termicznej [40, 44, 46, 54, 57], elektrycznej [20] oraz chemicznej [15, 39, 62]. W innej publikacji [7] zwrócono uwagę na możliwość oszczędności energii elektrycznej, analizując przypadek akumulacji energii hamowania tramwaju. Opisano także zintegrowany układ do magazynowania energii oparty na termochemicznej sorpcji ciało stałe-gaz [32].

\section{Podsumowanie}

Autorzy są przekonani, że zgromadzona literatura i szczegółowa analiza stanów badań w poszczególnych obszarach badawczych pozwoli na przygotowanie projektów badawczych dotyczących zaawansowanych technologii w energetyce i w konsekwencji na skonstruowanie oraz zbudowanie nowego urządzenia prototypowego.

\section{Literatura}

[1] Arakawa H. et al.: Catalysis research of relevance to carbon management: Progress, Challenges, and Opportunities, Chem. Rev., 101 (2000), 953-996.

[2] Bao J., Zhao L.: A review of working fluid and expander selections for organic Rankine cycle, Renew. Sustain. Energy Rev., 24 (2013), 325-342.

[3] Bazaga-Garcia M., Colodrero R.M.P., Papadaki M., Garczarek P., Zoń J., Olivera-Pastor P., Losilla E.R., León-Reina L., Aranda M.A.G., Choquesillo-Lazarte D., Demadis K.D., Cabeza A.: Guest molecule-responsive functional calcium phosphonate frameworks for tuned proton conductivity, J. Am. Chem. Soc., 136 (2014), 5731-5739.

[4] Bhavsar S., Najera M., Solunke R., Veser G.: Chemical looping: To combustion and beyond, Catalysis Today, 228 (2014), 96-105.

[5] Bielowicz B.: A new technological classification of low-rank coal on the basis of Polish deposits, Fuel, 96 (2012), 497-510.

[6] Bukur D.B., Elbashir N.: Gas conversion: The clean energy of the future is the theme of NGCS-10 in Doha, Qatar, Ind. Eng. Chem. Res., 53 (2014), 1719-1719.

[7] Ceraolo M., Lutzemberger G.: Stationary and on-board storage systems to enhance energy and cost efficiency of tramways, J. Power Sources, 264 (2014), 128-139.

[8] Chen H., Goswami D.Y., Stefanakos E.K.: A review of thermodynamic cycles and working fluids for the conversion of low-grade heat, Renew. Sustain. Energy Rev., 14 (2010), 3059-3067. 
[9] Chen X., Shen S., Guo L., Mao S.S.: Semiconductor-based photocatalytic hydrogen generation, Chem. Rev., 110 (2010), 6503-6570.

[10] Czakiert T., Sztekler K., Karski S., Markiewicz D., Nowak W.: Oxy-fuel circulating fluidized bed combustion in a small pilot-scale test rig, Fuel Proc. Technol., 91 (2010), 1617-1623.

[11] Czakiert T., Muskala W., Janowska S., Krawczyk G., Borecki P., Jesionowski Ł., Nowak W.: Combustible matter conversion in an oxy-fuel circulating fluidized-bed (CFB) environment, Energy Fuels, 26 (2012), 5437-5445.

[12] Dutta K., Daverey A., Lin J.G.: Evolution retrospective for alternative fuels: First to fourth generation, Renew. Energy, 69 (2014), 114-122.

[13] Dutta S.: A review on production, storage of hydrogen ann its utilization as an energy resource, J. Ind. Eng. Chem., 20 (2014), 1148-1156.

[14] Elbashir N.O., Mirodatos C., Holmen A., Bukur D.B.: Preface. Natural gas conversion: Current status and potentials in the light of the NGCS-10, Catalysis Today, 228 (2014), 1-4.

[15] Escudero-González J., López-Jiménez P.M.: Iron redox battery as electrical energy storage system in the Spanish energetic framework, Electrical Power Energy Systems, 61 (2014), 421-428.

[16] Fan L.S.: Chemical Looping Systems for Fossil Energy Conversion, Wiley, New York 2010.

[17] Fernández A., Dieste J.A.: Low and medium temperature solar thermal collector based in innovative materials and improved heat exchange performance, Energy Conversion Management, 75 (2013), 118-129.

[18] Fujitsuka H., Ashida R., Kawase M., Miura K.: Examination of low-temperature oxidation of low-rank coals, aiming at understanding their self-ignition tendency, Energy Fuels, 28 (2014), 2402-2407.

[19] Gnutek Z., Kolasiński P.: The application of rotary vane expanders in organic rankine cycle systems - thermodynamic description and experimental results, J. Eng. Gas Turbine Power-Trans. ASME, 135 (2013), 61-69.

[20] Hadjipaschalis I., Poullikkas A., Efthimiou V.: Overview of current and future energy storage technologies for electric power applications, Renew. Sustain. Energy Rev., 13 (2009), 1513-1522.

[21] Hairuddin A.A., Yusaf T., Wandel A.P.: Experimental investigation of intake diesel aerosol fuel homogeneous charge compression ignition (HCCI) engine combustion and emissions, Renew. Sustain. Energy Rev., 32 (2014), 739-761.

[22] Han Z., Eisenberg R.: Fuel from water: The photochemical generation of hydrogen from water, Acc. Chem. Res., 2014, http://dx.doi.org/10.10221/ar5001605.

[23] Ikealumba W.C., Wu H.: Some recent advances in liquefied natural gas (LNG) production, spill, dispersion, and safety, Energy Fuels, 28 (2014), 3556-3586.

[24] Imran S., Emberson D.R., Diez A., Wen D.S., Crookes R.J., Korakianitis T.: Natural gas fueled compression ignition engine performance and emissions maps with diesel and RME pilot fuels, Applied Energy, 124 (2014), 354-365.

[25] Ismail A.A., Bahnemann D.W.: Photochemical splitting of water foe hydrogen production by photocatalysis: A review, Solar Energy Mat. Solar Cells, 128 (2014), 85-101. 
[26] Iulianelli A., Ribeirinha P., Mendes A., Basile A.: Methanol steam reforming for hydrogen generation via conventional and membrane reactors: A review, Renew. Sustain. Energy Rev., 29 (2014), 355-368.

[27] Joya K.S., Joya Y.F., Ocakoglu K., van de Krol R.: Water-splitting catalysis and solar fuel devices: Artificial leaves on the move, Angew. Chem. Int. Ed., 52 (2013), 10426-10437.

[28] Kalicka Z., Jerzak W., Kawecka-Cebula E.: The effect of combustion of natural gas with 21-29\%O2/CO2?N2 mixtures on emission of carbon monoxide, Arch. Environ. Protection, 39 (2013), 93-103.

[29] Lee S.W., Yang Y., Lee H.W., Ghasemi H., Kraemer D., Chen G., Cui Y.: An electrochemical system for efficiently harvesting low-grade heat energy, Nature Comm., 2014.

[30] Li C.Z.: Importance of volatile-char interactions during the pyrolysis and gasification of low-rank fuels - A review, Fuel, 112 (2013), 609-623.

[31] Li L., Wu Z., Yuan S., Zhang X.B.: Advances and challenges for flexible energy storage and conversion devices and systems, Energy Environ. Sci., 7 (2014), 2101-2122 .

[32] Li T.X., Wang R.Z., Yan T., Ishugah T.F.: Integrated energy storage and energy upgrade, combined cooling and heating supply, and waste heat recovery with solid-gas thermochemical sorption heat transformer, Int. J. Heat Mass Transfer, 76 (2014), 237-246.

[33] Low F., De Girolamo A., Dai B.Q., Zhang L.: Emission of organically bound elements during the pyrolysis and char oxidation of lignites in air and oxyfuel combustion mode, Energy Fuels, 28 (2014), 4167-4176.

[34] Luyben W.L.: Chemical process engineering principles of combustion turbines, Energy Fuels, 27 (2013), 6316-6321.

[35] Mahlia T.M.I., Saktisahdan T.J., Jannifar A., Hasan M.H., Matseelar H.S.C.: A review of available methods and development on energy storage; technology update, Renew. Sustain. Energy Rev., 33 (2014), 532-545.

[36] Manil P., Baudouy B., Clément S., Devaux M., Durante M., Fazilleau P., Ferracin P., Fessia P., Garcia Munoz J.E., Garcia L., Gauthier R., Oberli L., Perez J.C., Pietrowicz S., Rifflet L.M., de Rijk G., Rondeaux F., Todesco E.: Development and coil fabrication test of the $\mathrm{Nb}_{3} \mathrm{Sn}$ dipole magnet FRESCA2, IEEE Trans. Appl. Superconduc., 24 (2014), 4001705.

[37] Mendiara T., de Diego L.F., Garcia-Labiano F., Gayán P., Adánez A.A.J.: On the use of a highly reactive iron ore in Chemical Looping Combustion of different coals, Fuel, 126 (2014), 239-249.

[38] Mendiara T., Izquierdo M.T., Abad A., Gayán P., Garcia-Labiano F., de Diego L.F., Adánez J.: Mercury release and speciation in chemical looping combustion of coal, Energy Fuel, 28 (2014), 2786-2794.

[39] Müller K., Städter M., Rachow F., Hoffmannbeck D., Scmeißer D.: Sabatier-based $\mathrm{CO}_{2}$-methanation by catalytic conversion, Environ, Earth Sci., 70 (2013), 3771-3778 .

[40] Nithyanandam K., Pitchumani R.: Design of a latent thermal energy storage system with embedded heat pipes, Appl. Energy, 126 (2014), 266-280. 
[41] Nozik A.J., Miller J.: Introduction to solar photon conversion, Chem. Rev., 110 (2010), 6443-6445.

[42] Okasha F., Zaater G., El-Emam S., Awad M., Zeidan E.: Co-combustion of biomass and gaseounfiguration of fluidized bed: Combustion characteristic, Fuel, 133 (2014), 143-152.

[43] Osman H., Jangam S.V., Lease J.D., Mujumdar A.S.: Drying of low-rank coal (LRC) - A review of recent patents and innovations, Drying Techn., 29 (2011), 1763-1783.

[44] Pardo P., Deydier A., Anxionnaz-Minvielle Z., Rougé S., Cabassud M., Cognet P.: A review on high temperature thermochemical heat energy storage, Renew. Sustain. Energy Rev., 32 (2014), 591-610.

[45] Perera M.S.A., Ranjith P.G., Choi S.K., Bouazza A., Kodikara J., Airey D.: A review of coal properties pertinent to carbon dioxide sequestration in coal seams: with special reference to Victorian brown coals, Environ. Earth Sci, 64 (2011), 223-235.

[46] Pielichowska K., Pielichowski K.: Phase change materials for thermal energy storage, Progress Mat. Sci., 65 (2014), 67-123.

[47] Pietrowicz S., Baudouy B.: Numerical study of the thermal behavior of an $\mathrm{Nb}_{3} \mathrm{Sn}$ high field magnet in He II, Cryogenics, 53 (2013), 72-77.

[48] Quoilin S., Van Den Broek M., Declaye S., Dewallef P., Lemort V.: Techno-economic survey of organic rankine cycle (ORC) systems, Renew. Sustain. Energy Rev., 22 (2013), 168-186.

[49] Rady A.C., Giddey S., Kulkarni A., Badwall S.P.S., Bhattacharya S., Ladewig B.P.: Direct carbon fuel cell operation on brown coal, Applied Energy, 120 (2014), 56-64.

[50] Saidur R., Rezaei M., Muzammil W.K., Hassan M.H., Paria S., Hasanuzzaman M.: Technologies to recover exhaust heat from internal combustion engines, Renew. Sustain. Energy Rev., 16 (2012), 5649-5659.

[51] Saucedo M.A., Lim J.Y., Dennis J.S., Scott S.A.: $\mathrm{CO}_{2}$-gasification of lignite coal in the presence of an iron - based oxygen carrier for chemical-looping combustion, Fuel, 127 (2014), 186-201.

[52] Sevill M., Mokaya R.: Energy storage applications of activated carbons: supecapacitor and hydrogen storage, Energy Environ. Sci., 7 (2014), 1250-1280.

[53] Tchanche B.F., Lambrinos G., Frangoudakis A., Papadakis G.: Low-grade heat conversion into power using organic rankine cycles - A review of various applications, Renew. Sustain. Energy Rev., 15 (2011), 3963-3979.

[54] Tian Y., Zhao C.Y.: A review of solar collectors and thermal energy storage in solar thermal applications, Appl. Energy, 104 (2013), 538-553.

[55] Uddin Md. N., Wan Daud W.M.A.: Technological diversity and economics: Coupling effects on hydrogen production from biomass, Energy Fuels, 28 (2014), 4300-4320.

[56] Vohra M., Manwar J., Manmode R., Padgilwar S., Patil S.: Bioethanol production: Feedstock and current technologies, J. Environ. Chem. Eng., 2 (2014), 573-584.

[57] Xu J., Wang R.Z., Li Y.: A review of available technologies for seasonal thermal energy storage, Solar Energy, 103 (2014), 610-638. 
[58] Yaakob Z., Narayanan B.N., Padikkaparambil S., Surya U.K., Mohammed A.P.: A review on the oxidation stability of biodiesel, Renew. Sustain. Energy Rev., 35 (2014), 136-153.

[59] Yaliwal V.S., Banapurmath N.R., Gireesh N.M., Tewari P.G.: Production and utilization of renewable and sustainable gaseous fuel for power generation applications: A review of literature, Renew. Sustain. Energy Rev., 34 (2014), 608-627.

[60] Yan Y., Yang S., Blake A.J., Schröder M.: Studies on metal-organic frameworks of $\mathrm{Cu}(\mathrm{II})$ with isophthalate linkers for hydrogen storage, Acc. Chem Res., 47 (2014), 296-307.

[61] Yu J., Tahmasebi A., Han Y., Yin F., Li X.: A review on water in low rank coals: The existence, interaction with coal structure and effects on coal utilization, Fuel Processing Technol., 106 (2013), 9-20.

[62] Zhang J., Li J., Li Y., Zhao Y.: Hydrogen Generation, Storage and Utilization, Wiley, New York 2014.

[63] Zhang J., Wang Y., Dong L., Gao S., Xu G.: Decoupling gasification: approach principle and technology justification, Energy Fuels, 24 (2010), 6223-6232.

[64] Zhang J., Wu R., Zhang G., Yu J., Yao C., Wang Y., Gao S., Xu G.: Technical review on thermochemical conversion based on decoupling for solid carbonaceous fuels, Energy Fuels 27 (2014), 1951-1966.

[65] Zhong S., Baitalow F., Nikityuk P., Gutte H., Meyer B.: The effect of particle size on the strength parameters of German brown coal and its chars, Fuel, 125 (2014), 200-205.

\title{
NEW MATERIALS AND PROCESSES IN CONVERSION AND STORAGE OF ENERGY - SELECTED PROBLEMS
}

\begin{abstract}
S u m m a r y
On the basis of literature studies the examples of currently used technologies and materials for energy conversion and storage were selected and described. Taking into consideration increasing domestic demand for energy, limited resources and climate conditions, authors have presented several energy conversion and storage related topics. Literature studies were carried out on the basis of databases SciFinder and Current Contents in perspective past four years. Only in exceptional cases dating back to the older literature.
\end{abstract}

Keywords: brown coal, natural gas, coal, hydrogen as fuel, organic Rankine cycle, energy conversion, storage energy

DOI: $10.7862 / \mathrm{rm} .2015 .19$

Otrzymano/received: $14.09 .2014 r$.

Zaakceptowano/accepted:10.03.2015 r. 